УДК 378

DOI https://doi.org/10.26661/2663-5925-2020-1-08

\title{
ВИКОРИСТАННЯ ФІЗКУЛЬТУРНО-ОЗДОРОВЧИХ ТЕХНОЛОГІЙ У ПРОФЕСІЙНІЙ ДІЯЛЬНОСТІ ВИКЛАДАЧІВ ВИЩИХ НАВЧАЛЬНИХ ЗАКЛАДІВ
}

\author{
Терьохіна О. Л. \\ кандидат педагогічних наук, \\ старший викладач кафедри олімпійських та неолімпійських видів спорту \\ Національний університет «Запорізька політехніка» \\ вул. Жуковського, 64, Запоріжжя, Украӥна \\ orcid.org/0000-0001-5835-4846 \\ terehaol1974@gmail.com \\ Кириченко О. В. \\ старший викладач кафедри олімпійських та неолімпійських видів спорту \\ Національний університет «Запорізька політехніка» \\ вул. Жуковського, 64, Запоріжжя, Україна \\ orcid.org/0000-0001-7136-0984 \\ lena181961@ukr.net \\ Дуднік Ю. І. \\ старший викладач кафедри олімпійських та неолімпійських видів спорту \\ Національний університет «Запорізька політехніка» \\ вул. Жуковського, 64, Запоріжжя, Україна \\ orcid.org/0000-0002-8034-2697 \\ dudila2009@gmail.com
}

Ключові слова: фізкультурнооздоровчі технології, критерій, показник, рівень, фізичне виховання.
Кожен вид дисципліни потребує постійного розвитку, пошуку нових шляхів реалізації тощо. Усебічний розвиток особистості реалізується через формування здорового способу життя. У статті наведено основні показники, критерії та рівні готовності викладача фізичного виховання вищого навчального закладу до використання фізкультурно-оздоровчих технологій у професійній діяльності. Нині в сучасній освіті закономірним виявляється рух викладачів фізичного виховання до використання фізкультурно-оздоровчих технологій на практичних заняттях із фізичного виховання, зміни концепції спортивної орієнтації фізичної культури на оздоровчу, що спрямовується на створення варіативних форм, розроблення та апробацію нових технологій тощо. Модернізація системи підготовки фахівців педагогічного профілю у ВНЗ галузі фізичної культури та спорту є важливим елементом педагогіки вищої школи. Після обговорення широкого кола проблем, пов'язаних із подальшим розвитком міжнародної співпраці в галузі освіти, науки, культури, інформації та комунікації, новими стратегічним підходами було визнано: поліпшення якості освіти через підвищення рівня викладання, навчання, адекватності й ефективності; освіта в дусі цінностей, демократичної громадянськості, прав людини, терпимості й діалогу задля примирення та миру; посилення уваги до вищої освіти через їі важливість для інноваційної діяльності та формування міцніших суспільств й економік, а також проблеми зі вступом на цей рівень навчання; формування глобальної платформи для обговорення освітніх інновацій і реформ із погляду майбутнього освіти; надання нового імпульсу зусиллям щодо забезпечення освіти для всіх через формування нових партнерських зв'язків. Найважливішими компонентами готовності викладача фізичного виховання вищого закладу освіти до використання фізкультурно-оздоровчих технологій у професійній діяльності є мотиваційний, когнітивний, особистісний, фізичний компоненти. 


\title{
USE OF PHYSICAL AND HEALTH TECHNOLOGIES IN PROFESSIONAL ACTIVITIES OF TEACHERS OF HIGHER EDUCATION UNITS
}

\author{
Terokhina O. L. \\ Candidate of Pedagogical Sciences, \\ Assistant Professor at the Department of Olympic and non-Olympic Sports \\ "Zaporizhzhia Polytechnic" National University \\ Zhukovskoho str., 64, Zaporizhzhia, Ukraine \\ orcid.org/0000-0001-5835-4846 \\ terehaol1974@gmail.com \\ Kirichenko E. V. \\ Assistant Professor at the Department of Olympic and non-Olympic Sports \\ "Zaporizhzhia Polytechnic" National University \\ Zhukovskoho str., 64, Zaporizhzhia, Ukraine \\ orcid.org/0000-0001-7136-0984 \\ lena181961@ukr.net \\ Dudnyk Yu. I. \\ Assistant Professor at the Department of Olympic and non-Olympic Sports \\ "Zaporizhzhia Polytechnic" National University \\ Zhukovskoho str., 64, Zaporizhzhia, Ukraine \\ orcid.org/0000-0002-8034-2697 \\ dudila2009@gmail.com
}

Key words: physical culture and health technologies, criterion, indicator, level, physical education.
Any discipline requires constant development, finding new ways of implementation, submission and more. All-round personality development is realized through the formation of a healthy way life.

This article describes the indicators, criteria and levels of readiness of a teacher of physical education of a higher education institution to use physical education and health technologies in professional activity. Nowadays, in modern education, the movement of teachers of physical education towards the use of physical and recreational technologies in practical classes of physical education, the change of the concept of sports orientation of physical culture on health, which is directed to creation of variational forms, development and approbation of new technologies, is natural. Modernization of the system of training of pedagogical specialists in higher education in the field of physical culture and sports is an important element of higher education pedagogy. After discussing a wide range of issues related to the further development of international cooperation in the fields of education, science, culture, information and communication, the following strategic approaches were recognized: improving the quality of education through improved teaching, learning, relevance and effectiveness; education in the spirit of values, democratic citizenship, human rights, tolerance and dialogue for reconciliation and peace; increasing attention to higher education because of its importance for innovation and the formation of stronger societies and economies, as well as the difficulty of entering this level of education; the creation of a global platform for discussing educational innovations and reforms with a view to future education; giving new impetus to education efforts for all through the formation of new partnerships. Physical education and health technologies do not change the logic of the educational process, but abolish rigid normativity and authoritarianism of curricula on physical education, form a positive motivation for the subject of "physical education", contribute to the health effect, correct the health status of all participants of this process. 
Постановка проблеми. Підвищення якості професійної підготовки та підвищення кваліфікації 3 огляду на сучасні запити й тенденції розвитку високоефективних привабливих напрямів фізичної активності. Вектор діяльності викладача фізичного виховання вищого закладу освіти спрямовано на оздоровчу фізичну культуру. Значний інтерес у цьому контексті становлять фізкультурно-оздоровчі технології, де здоров'яформувальні та здоров'язбережувальні підходи взаємопов'язані та доповнюють один одного.

Мета статті. Завданням статті $\epsilon$ визначення критеріїв, рівнів і показників готовності викладача фізичного виховання ВНЗ до використання фізкультурно-оздоровчих технологій у професійній діяльності. Оцінювання готовності викладача фізичного виховання вищого закладу освіти до використання фізкультурно-оздоровчих технологій у професійній діяльності відбувається критеріально-рівневими інструментаріями компонентів цієї готовності. На основі проведеного аналізу української й зарубіжної науково-педагогічної літератури схарактеризовано понятійну конструкцію дослідження «фізкультурно-оздоровча технологія». Можна зробити висновок, що фізкультурно-оздоровча технологія - це цілеспрямована взаємодія учасників педагогічного процесу, в основу якого покладено різні види рухової діяльності, які спрямовані на отримання максимально можливого оздоровчого ефекту, реалізацію потреби людини в русі, здоров'ї та дбайливому ставленні до нього через свідоме регулювання фізичної активності. Загальними компонентами готовності викладача фізичного виховання ВН3 $€$ мотиваційний компонент, когнітивний компонент, особистісний компонент, фізичний компонент. Мотиваційний компонент. Наявність мотивації на досягнення успіху [1]. За такої мотивації дії викладача спрямовуються на досягнення позитивних результатів. Такі люди завжди активні, ініціативні, виявляють наполегливість у досягненні поставленої мети. Викладачі з такою мотивацією не бояться перешкод, а шукають шляхи їх подолання, віддають перевагу нестандартним завданням, мають потребу в ефективності своїх дій. Коли їхні дії приводять до досягнення поставленої мети, відчувають задоволення та радість. Викладач, який мотивований на успіх, характеризується рішучістю у нестандартних ситуаціях, готовністю брати на себе відповідальність, адекватною самооцінкою. Мотиваційний компонент готовності викладачів фізичного виховання вищих закладів освіти до використання фізкультурно-оздоровчих технологій у професійній діяльності відображає відповідну психологічну готовність, визначає ставлення викладачів до освіти у вищому закладі освіти, прагнення опанувати обрану спе- ціальність, розуміння ним педагогічних завдань, усвідомлення відповідальності, бажання досягти успіху в реалізації фізкультурно-оздоровчих технологій, інтерес до фізичного виховання та фізкультурно-оздоровчих технологій зокрема, наполегливість у реалізації своїх професійних планів. Професійна діяльність викладачів фізичного виховання 3 використанням фізкультурно-оздоровчих технологій висуває підвищені вимоги до освітньої підготовки. Емоційний компонент полягає у відсутності емоційного напруження, страху перед аудиторією. Як відомо, будь-яка діяльність людини пов'язана з емоціями, тобто має емоційне забарвлення. Чималу роль відіграє в цьому й те, які емоції викликає та чи інша діяльність: позитивні, нейтральні чи негативні. Емоційна напруженість у педагогічній діяльності характеризується переважанням негативних емоцій, перезбудженням, виснаженням нервової системи, наявністю страху перед аудиторією, студентами [2]. Емоційне напруження можуть викликати недоліки в управлінні своєю діяльністю, особливо такі шкідливі звички: відкладати справу на останній момент, не досить сумлінно готуватися до лекцій, занять, систематично запізнюватися, не виконувати власні плани тощо. Відсутність емоційного напруження має поєднуватися зі здатністю викладача створювати довільно потрібний настрій, найповніше використовувати свої потенційні можливості. Когнітивний компонент готовності викладачів до використання фізкультурно-оздоровчих технологій у професійній діяльності забезпечує їхню науково-теоретичну готовність, що характеризують такі групи, як: психолого-педагогічні, медико-біологічні, спеціальні (щодо використання фізкультурно-оздоровлювальних технологій) [3]. Використання фізкультурно- оздоровлювальних технологій являє собою практичну фізкультурно-оздоровчу діяльність викладача фізичного виховання, яка потребує значної рухової ерудиції, варіативності вправ, що спрямовані на розвиток витривалості, швидкості, сили, гнучкості, координаційних здібностей; опанування вправ танцювальних напрямів, фізичних вправ з єдиноборств, вправ таких специфічних напрямів фізкультурнооздоровлювальних технологій, як йога, пілатес тощо; вміння швидко перемикати увагу з одного виду рухової діяльності на інший. Професійно-педагогічний компонент полягає в умінні приймати педагогічно доцільне рішення в нестандартних ситуаціях. Це вміння передбачає не тільки правильний аналіз створеної ситуації, а й здатність викладача до зміни способів і прийомів діяльності у разі зміни педагогічної ситуації.

Методологічна рефлексія пов'язана 3 умінням аналізувати власну наукову діяльність, характеризує перехід мислення від рецептурно-відбиткового 
підходу до конструктивно-діяльнісного, що забезпечує методологічне й теоретичне осмислення педагогічної науки i практики, спрямованість на особистісно орієнтовану освіту [4]. Методологічна рефлексія сприяє критичному осмисленню та творчому застосуванню певних концепцій, форм і методів пізнання. Методологічна рефлексія викладача відбиває певний рівень розвитку професійно-педагогічної спрямованості. Для цієї спрямованості характерна усвідомлена та емоційно виражена орієнтація особистості на педагогічну діяльність [5]. Методологічна рефлексія викладача забезпечує розвиток педагогічних здібностей, зокрема перцептивних і конструктивних, що впливають на досягнення педагогічної майстерності. Швидкість реакції на поведінку аудиторій окремих студентів - ця ознака, безумовно, пов'язана $з$ таким емоційним станом, як самовладання в різних педагогічних ситуаціях.

Особистісний компонент готовності викладачів фізичного виховання вищих закладів освіти до використання фізкультурно-оздоровчих технологій у професійній діяльності характеризує відповідна психофізіологічна готовність [6]. Психофізіологічна готовність передбачає наявність відповідних передумов для оволодіння педагогічною діяльністю, формування професійно значущих особистісних якостей. Професійна діяльність викладачів фізичного виховання щодо використання фізкультурно-оздоровчих технологій висуває певні вимоги до нейродинаміки. Викладач повинен уміти концентрувати увагу, володіти високою працездатністю, бути активним, відчувати час, простір, організовувати та спрямовувати зусилля, мати гарну пам’ять тощо, при всьому цьому ще й встигати спілкуватися і керувати процесом засвоєння студентами фізкультурно-оздоровчих технологій. Однією з важливих передумов результативної професійної діяльності викладачів фізичного виховання щодо використання фізкультурно-оздоровчих технологій $є$ розвиток його фізичних якостей [7]. Фізичний компонент викладачів фізичного виховання до використання фізкультурно-оздоровлювальних технологій у професійній діяльності відображає рухову готовність. Формуванню рухової фізичної готовності, а саме розвитку п'яти фізичних якостей (витривалості, сили, швидкості, гнучкості, координаційних здібностей) приділяється особлива увага, тому що засоби фізкультурно-оздоровчих технологій - це фізичні вправи, що потребують безпомилкової чіткої технічної демонстрації. У процесі дослідження нами було визначено й схарактеризовано систему показників, покладених в основу діагностики стану готовності викладачів фізичного виховання у вищих закладах освіти до використання фізкультурно-оздоровлювальних технологій у професійній діяльності, а саме показниками мотиваційного компоненту $€$ мотиви опанування обраної професії викладача фізичного виховання та фізкультурно-оздоровчих технологій [8].

Виклад основного матеріалу дослідження. Проблема розвитку впровадження сучасних фізкультурно-оздоровлювальних технологій дослідників цікавить уже досить тривалий час. Аналізом та описом класичних відомих методик і розробленням нових, експериментальних, займалися дослідники Н. Щуркова, П. Джуринський, Л. Волков, Г. Дзяк, Ю. Фурман, Л. Заніна та інші, які довели, що пошук шляхів удосконалення традиційних програм фізичної культури, оздоровлення учнів загальноосвітніх шкіл $є$ предметом систематичних наукових досліджень, що здійснюються як українськими, так i закордонними науковцями. Багато 3 них схиляється до думки, що насамперед потрібно здійснювати постійний пошук найефективніших засобів, методів, технологій, програм і педагогічних систем фізичної культури, оздоровлення та спортивної підготовки всіх прошарків населення нашої країни.

Критерій - суттєва, відмінна ознака, на підставі якої проводиться оцінка, визначення або класифікація будь-чого. Критерії готовності викладачів фізичного виховання вищих навчальних закладів до використання фізкультурно-оздоровлювальних технологій у професійній діяльності ми розглядаємо як якісні і кількісні ознаки показників готовності, а саме: мотиви, знання, практичні вміння, навички, досвід, особистісні і професійні якості (комунікативність, організаційність, активність педагогічна та соматична, фізична працездатність), фізичні якості: витривалість, сила, швидкість, гнучкість, координація.

Рівень - порівняльна величина, що характеризує будь-що з погляду розміру, інтенсивності, якості тощо; міра, порівняльна якість чогось. Рівні сформованості готовності викладачів фізичного виховання вищих закладів освіти до використання фізкультурно-оздоровлювальних технологій у професійній діяльності виражають ступінь прояву відповідного критерію готовності: оптимальний, достатній, допустимий, критичний, незадовільний. Кожен із рівнів містить риси попереднього, проте відрізняються вони один від одного ступенем прояву критеріїв, що характеризують відповідну готовність.

Висновки. У сфері фізкультурно-оздоровлювальних технологій постійно з'являються нові види, напрями, методи та методики, як, наприклад «кроссфіт», «TRX петлі», «йогалатес» тощо. Необхідно зазначити, що недосвідчені викладачі розв'язують цю проблему активними та практичними методами, такими як візуальні й аудіальні демонстрації видів фізкультурно-оздоровлювальних технологій. Фізкультурно-оздоровлювальні технології постійно розширюють діапазон напрямів i, як наслідок, затребувані сучасною студентською молоддю як засіб фізичного вдосконалення. 


\section{ЛІТЕРАТУРА}

1. Верблюдов І.Б. Порівняльне дослідження дії вправ аеробної спрямованості в індивідуальних тренувально-оздоровчих програмах студентів педагогічних ВНЗ. Молода спортивна наука України. Луганськ, 2003. № 7. T. 2. С. 321-323.

2. Баль Л.В. Новое направление детских профилактических программ - детское движение в защиту здоровья. Школа здоровья. 1998. № 1. С. 17-22.

3. Бальсевич В.К. Корунец А.И., Марков Ю.Н. Спортизация общеобразовательной школы как новый вектор взаимодействия олимпийского массового и юношеского спорта. Молодёжь - Наука - Олимпизм : матер. межд. форума. Москва: 1998. С. 46-48.

4. Вільчковський Е.С., Курок О.І. Теорія і методика фізичного виховання дітей дошкільного віку : навч. посіб. Суми : ВТД «Університетська книга», 2008. 428 с.

5. Волков Л.В. Теорія і методика дитячого та юнацького спорту. Київ : Олімпійська література, 2002. $296 \mathrm{c}$.

6. Давыдов В.Ю., Шамардин А.И., Краснова Г.О. Новые фитнес-системы : учеб. пособ. Волгоград : ВГАФК, 2005. $287 \mathrm{c}$.

7. Дудіцька С.П., Зендик О.В. Сучасні фізкультурно-оздоровчі технології у фізичному вихованні. Теорія та методика фіз. виховання і спорту. 2002. № 2-3. С. 81-82.

8. Долинний Ю.О. Методичні особливості використання психорегуляції і нетрадиційних методів дихальної гімнастики в процесі занять з фізичного виховання в СМО. Молода спортивна наука України. Луганськ, 2003. № 7. Т. 2. С. 283-286.

\section{REFERENCES}

9. Verblyudov I. (2003) Porivnyal'ne doslidzhennya diyi vprav aerobnoyi spryamovanosti v indyvidual'nykh trenuval'no-ozdorovchykh prohramakh studentiv pedahohichnyyi VNZ [Comparative Study of Aerobic Exercise Exercise Activity in Individual Training Programs of Students of Pedagogical University]. Young sports science of Ukraine. Vol. 2. P. 321-323.

10. Bal L. (1998) Novoye napravleniye detskikh profilakticheskikh programm - detskoye dvizheniye v zashchitu zdorov'ya [A new direction in children's preventive programs is the children's movement in defense of health]. School of Health. Vol. 1. P. 17-22.

11. Balsevich V., Korunets A., Markov Y. (1998) Sportizatsiya obshcheobrazovatel'noy shkoly kak novyy vektor vzaimodeystviya olimpiyskogo massovogo i yunosheskogo sporta [Sportization of a comprehensive school as a new vector of interaction between Olympic mass and youth sports]. Youth - Science Olympism : Mater. Int. forum. Vol. 1. P. 46-48.

12. Vilchkovsky E., Kurok O. (2008) Teoriya i metodyka fizychnoho vykhovannya ditey doshkil'noho viku [Theory and methodology of physical education of preschool children]. Sums University Book. P. 428.

13. Volkov L. (2002) Teoriya i metodyka dytyachoho ta yunats'koho sportu [Theory and methodology of children's and youth sports]. Kyiv Olympic Literature. P. 296.

14. Davydov V., Shamardin A., Krasnova G. (2005) Novyye fitnes-sistemy [New fitness systems]. Volgograd textbook. P. 287.

15. Duditska S., Zendyk O. Suchasni fizkul'turno-ozdorovchi tekhnolohiyi u fizychnomu vykhovanni [Modern Physical Culture and Health Technologies in Physical Education]. Theory and Method of Phys. education and sports. Vol. 2-3. P. 81-82.

16. Dolynnyi Y. (2003) Metodychni osoblyvosti vykorystannya psykhorehulyatsiyi i netradytsiynykh metodiv dykhal'noyi himnastyky v protsesi zanyat' z fizychnoho vykhovannya v SMO [Methodical features of the use of psychoregulation and non-traditional methods of respiratory gymnastics in the process of physical education classes in QMS]. Young sports science of Ukraine. Vol. 2. P. 283-286. 